Western Washington University

Western CEDAR

6-1995

\title{
Spatial Variation of Naticid Gastropod Predation in the Eocene of North-America
}

Thor A. Hansen

Western Washington University, thor.hansen@wwu.edu

Patricia H. Kelley

Follow this and additional works at: https://cedar.wwu.edu/geology_facpubs

Part of the Geology Commons

\section{Recommended Citation}

Hansen, Thor A. and Kelley, Patricia H., "Spatial Variation of Naticid Gastropod Predation in the Eocene of North-America" (1995). Geology Faculty Publications. 1.

https://cedar.wwu.edu/geology_facpubs/1 


\section{Spatial Variation of Naticid Gastropod Predation in the Eocene of North America}

\author{
THOR A. HANSEN \\ Department of Geology, \\ Western Washington University, \\ Bellingham, WA 98225 \\ PATRICIA H. KELLEY \\ Department of Geology and \\ Geological Engineering, \\ University of North Dakota, \\ P.O. Box 8358, \\ Grand Forks, ND 58202
}

PALAIOS, 1995, V. 10, p. 268-278

Although, the fossil record of naticid gastropod drilling has played an important role in the controversy over predator-prey evolution, little is known about variation of drilling frequencies within single horizons or how predation patterns are influenced by environmental variables. Without an understanding of spatial variation in drilling, temporal patterns in drilling are difficult to interpret. We surveyed 27,554 specimens of molluscs from the Cook Mountain interval (upper middle Eocene) and Jackson Group (late Eocene) of the U.S. Gulf and Atlantic Coastal Plain to document spatial variation in naticid drilling frequencies.

The Jackson Group assemblages from the Moodys Branch and Yazoo formations were sampled along a depth gradient in order to compare drilling frequencies to environmental variables within a single climatic zone. There was a statistically significant difference between drilling frequency of the inner to middle shelf Moodys Branch Formation (mean = $8.3 \%$ ) and the outer shelf Yazoo Formation $($ mean $=21.2 \%$; chi square
$=49.58, P \ll 0.001)$, but there was no significant bathymetric trend in drilling frequencies among the five assemblages of the Moodys Branch. Drilling frequency was not related to substrate type within the Moodys Branch. Drilling, however, was correlated with species diversity of Moodys Branch assemblages ( $r=$ $0.50, P<0.01$ ). Drilling frequency was significantly correlated with the percentage of naticids in each assemblage $(r=0.77, P<0.001)$ and the percentage of certain prey species of the bivalve families Lucinidae and Corbulidae, and the gastropod families Turritellidae and Hipponicidae $(r=0.80, P<0.001)$. These preferred species represented $40 \%$ of the naticid victims, but only $16 \%$ of the assemblages.

Cook Mountain assemblages represented marine inner to middle shelf environments from Virginia, Alabama, Louisiana, and Texas. Naticid drilling frequencies of the entire molluscan fauna ranged from 6.8$38.7 \%$ with a mean of $22 \%$. In the Cook Mountain, three preferred species (of the families Turritellidae, Lucinidae, and Noetiidae), representing $24 \%$ of the total individuals, accounted for $44 \%$ of the drilled individuals. As in the Moodys Branch Formation, Cook Mountain assemblages showed a significant correlation between relative abundance of preferred species and drilling frequency of samples $(r=0.585, P<$ 0.05). The dependence of naticid drilling on the availability of preferred prey species indicates a possible behavioral inflexibility in naticid predation patterns.

The Virginia Cook Mountain fauna exhibited significantly greater drilling frequencies (mean $=30.3 \%$, $n=4$ samples) than did the Gulf Coast assemblages (mean $=18.0 \%$, $n=11$ samples; Mann-Whitney $U$-test, $P<0.01)$. This result is consistent with a trend found by some previous workers of an equatorward decrease in naticid drilling.

\section{INTRODUCTION}

The drilling gastropod family $\mathrm{Na}$ ticidae has figured prominently in the debate over escalation in predatorprey systems and in the study of coevolution. Vermeij (1987) used data on drilling frequencies to argue that biological hazards such as predation, and aptations to these hazards, have increased during the Phanerozoic (the "hypothesis of escalation"). However, the studies compiled by Vermeij typically included one or a few samples (taken from single lithofacies), which were then used to characterize the drilling frequency of an entire age. Moreover, analysis of these limited data necessarily meant that drilling frequencies from very different environments were compared through time. Vermeij recognized these deficiencies in the existing literature when he called for more research into drilling patterns in the fossil record and cautioned that only "similar nonbiological environments" should be compared through time (Vermeij, 1987 , p. 423). We know little about how naticid drilling patterns vary across different physical or biological environments in the Recent; existing information is sketchy and largely anecdotal. Nevertheless, without knowledge of the potential range of drilling frequencies within a single horizon and how drilling is influenced by environmental and biological variables such as substrate, water depth, latitude, and prey availability, it is impossible to assess the significance of temporal trends based on limited areal studies.

We have undertaken a comprehensive survey of naticid drilling patterns in the Cretaceous and Paleogene formations of the U.S. Atlantic and Gulf coastal plains. Over 46,000 
specimens of molluscs have been examined from 14 stratigraphic levels of formation scale. Kelley and Hansen (1993) reported largely on the temporal aspect of this study, assessing Cretaceous through Oligocene naticid predation in order to evaluate the hypothesis of escalation for the naticid predator-prey system. Concurrently with this temporal research, we evaluated spatial variation of naticid drilling in two widely distributed horizons: the middle Eocene Cook Mountain Formation and its stratigraphic equivalents (here termed the "Cook Mountain interval"), and the upper Eocene Moodys Branch Formation. The results of our spatial survey of naticid predation were incorporated into our evaluation of temporal trends (Kelley and Hansen, 1993). Here we document in detail our insights into how naticid predation varied among different lithofacies and biofacies within stratigraphic horizons.

\section{PREVIOUS STUDIES OF GEOGRAPHIC VARIATION IN DRILLING}

Previous works indicate that the geographic variability of Recent naticid drilling frequencies can be wide; for instance, drilling frequency on the bivalve Codakia bella from five sites on Guam varied from $17-75 \%$ (Vermeij, 1980). The same study also reported geographic variation in naticid drilling of the venerid Gafrarium pectinatum $(0-19 \%$, five sites on Guam), the cardiid Fragum fragum (0-23\%, 5 sites), and the tellinid Quidnipagus palatum (4-18\%, 5 sites). However, sample size of each taxon at most sites was relatively small (as few as 21 valves; only two of these samples had more than 100 valves). Drilling from all sources (including non-naticid drillers) on gastropods living on sand or mud varied from 5.9-30.3\% in the eastern Pacific and from 5-38\% in the tropical western Pacific and Indian Ocean (Vermeij, 1987; no sample size given).

Little is known about the variability of naticid predation with depth in modern oceans. Sander and Lalli (1982) studied species diversity and drilling frequency from all sources (including non-naticid drillers) from stations at $125 \mathrm{~m}, 175 \mathrm{~m}$, and $225 \mathrm{~m}$ water depth along a transect on the west coast of Barbados. Nine species, that each represented greater than $1 \%$ of the molluscan population were present at more than one station. Six of these species showed an increase in drilling frequency with depth (no statistical tests were performed). The trend is not convincing, however. Of the four species common to all three stations, only two showed a consistent trend of greater drilling with depth; drilling on one species was most intense at the intermediate depth, and the other species showed virtually no change.

More information is available on latitudinal variation in predator diversity and drilling frequencies. The diversity of all drilling gastropods increases towards the equator (Marincovich, 1977; Taylor and Taylor, 1977). In accord with this trend, naticid drilling frequencies on tropical turritellid gastropods are higher than on temperate species (Dudley and Vermeij, 1978). On the other hand, a survey of bivalve prey from 10 tropical and 7 cold temperate sites in both the Atlantic and Pacific Oceans revealed an equatorward decrease in naticid drilling frequency (Vermeij et al., 1989). In addition, Paleocene turritellids from Alabama exhibited lower naticid drilling frequencies (11 of 137 shells drilled) than did roughly contemporaneous species in Maryland and Virginia (33 of 179 shells drilled; Allmon et al., 1990).

Thus, previous studies on drilling patterns reveal that: 1$)$ the range of drilling frequencies on a prey population routinely varies from 5-30\% within relatively limited areas; 2 ) no convincing trend of drilling with water depth can be detected; and 3) evidence for a latitudinal trend in drilling frequencies is contradictory. However, these studies generally involved relatively small sample sizes and, in many cases, very limited geographic areas. We will document spatial trends in the fossil record using a much larger data base over a broad geographic area and range of environments.

\section{MATERIALS}

This study examines spatial variation in naticid predation within two well-sampled stratigraphic intervals from the U.S. Gulf and Atlantic coastal plains. The Cook Mountain "interval" (upper middle Eocene, Claiborne Group) comprises the roughly contemporaneous Piney Point Formation of Virginia, the upper Lisbon Formation of Alabama, and the Cook Mountain Formation of Louisiana and Texas; the upper Eocene interval includes the Moodys Branch and Yazoo formations of Louisiana and Mississippi (Jackson Group). These stratigraphic intervals represent time spans of approximately 2-3 m.y. each (Hansen, 1980).

All of the outcrops of these units expose richly fossiliferous and unconsolidated clastic marine sediments with aragonitic and calcitic shell mineralogies preserved. Shell preservation is excellent; most shells are robust and sometimes retain original coloration. Moodys Branch and Yazoo samples were taken from closely spaced dip and strike sections, allowing them to be placed in a well-constrained paleoenvironmental framework. This cohesiveness of the samples permitted comparison of drilling frequencies with environmental variables such as water depth and substrate, and with biological variables such as diversity and taxonomic composition of the fauna. The Cook Mountain interval includes samples from widely spaced outcrops along the Atlantic and Gulf Coastal Plain. Although these outcrops are environmentally unrelated and difficult to place along a depth gradient, they cover a large latitudinal range and allow examination of latitudinal variations in drilling.

Cook Mountain Interval.-In Virginia, the Cook Mountain interval is represented by the Piney Point Formation, exposed along the Pamunkey River. The Piney Point is a clayey, glauconitic, highly fossiliferous sand (Ward, 1984). Sedimentological and paleontological information indicate deposition in an inner-shelf environment of less than $100 \mathrm{~m}$ water depth (Strickland, 1984). Four sam- 
TABLE 1-Sample size (measured as number of individuals, \# IND), diversity (measured by $R^{\prime}=S-1 / \log N$ ), percent naticids ( $\%$ NAT), mean grain size (GSIZE) and percent preferred species (\% PREF) for the Cook Mountain interval. V, Virginia; A, Alabama; L, Louisiana; T, Texas.

\begin{tabular}{lrrccc}
\hline \hline Sample & \# IND & R $^{\prime}$ & \% NAT & GSIZE & \% PREF \\
\hline H76-64-2 V & 194 & 12 & 4.1 & 0.50 & 22.7 \\
H76-64-3 V & 259 & 12 & 4.3 & 0.33 & 30.2 \\
H76-64-5 V & 307 & 9 & 0 & 0.24 & 41.9 \\
H76-64-8 V & 236 & 8 & 0 & 0.22 & 19.1 \\
H76-31-3 A & 1234 & 14 & 7.9 & 0.35 & 73.0 \\
H76-49-1 A & 260 & 13 & 2.3 & 0.41 & 1.9 \\
H76-52 A & 210 & 14 & 3.3 & 0.34 & 4.3 \\
H76-34-13 A & 286 & 9 & 5.6 & 0.14 & 10.5 \\
H76-27-1 A & 316 & 13 & 2.2 & 0.29 & 7.8 \\
H76-76-1 L & 249 & 5 & 8.9 & 0.13 & 0 \\
H76-73-7 T & 282 & 7 & 11.3 & 0.05 & 0 \\
H76-73-8 T & 636 & 9 & 13.4 & 0.28 & 0 \\
H76-69-1 T & 224 & 3 & 21.9 & 0.09 & 0 \\
H76-69-2 T & 298 & 3 & 27.2 & 0.09 & 0 \\
H76-69-4 T & 245 & 5 & 11.9 & 0.41 & 0 \\
\hline
\end{tabular}

ples were taken from the Piney Point Formation (samples collected from each formation are listed in Table 1).

The upper Lisbon Formation in Alabama was collected from a road cut near Barryton in Choctaw County (sample number H76-31-3), along the banks of Little Stave Creek (H7634-13), and from exposures on the Alabama (H76-27-1) and Conecuh rivers (H76-49-1 and H76-52). The samples are very fossiliferous sands and clay-rich sands representing a shallow inner-shelf environment (Gardner, 1957).

Samples from the Cook Mountain Formation were collected from Saline Bayou in Louisiana (H76-76-1), and the Trinity (H76-73-7 and H7673-8) and Little Brazos rivers in Texas (H76-69-1, H76-69-2 and H76-694). The Cook Mountain is largely a silty or slightly sandy clay. Samples from Louisiana and the Trinity River represent open-marine conditions (Davis, 1962). Samples from the Little Brazos River contain a low-diversity molluscan assemblage with high juvenile mortality. The presence of pyrite and numerous crab concretions in this unit suggest low oxygen conditions. In addition, the Cook Mountain Formation at Little Brazos River is conformably overlain by marsh clays, suggesting a nearshore lagoonal environment (A.J. Scott, pers. comm., 1978). In total, 15 samples from the Cook Mountain interval were surveyed for drillholes.

Moodys Branch Formation.-The Moodys Branch Formation is a thin (3-14 m thick), fossiliferous glauconitic sand and sandy clay. The Moodys Branch is a transgressive marine shelf sand conformably overlain by the outer neritic Yazoo Formation (Dockery, 1976; Smith and Zumwalt, 1987).

Thirty-three bulk samples from eight sections in the Moodys Branch were processed for molluscs (washed, picked, identified and counted) and subjected to Q-Mode cluster analysis (Elder and Hansen, 1981). This analysis delineated six distinct molluscan assemblages (designated A-F, see Fig. 1). Depositional environments of the assemblages were interpreted using stratigraphic relationships and sedimentologic and taphonomic information (e.g., grain size, mineralogy, sedimentary structures, shell condition and orientation, and trace fossil assemblages; Elder and Hansen, 1981). Environmental interpretations indicate a general onshore-offshore transect as follows: assemblage $A$, fine sand in an open bay or lagoon; assemblage $B$, medium to fine sand in a nearshore wave-influenced en- vironment; assemblage $\mathrm{C}$, clay-rich fine sand on the inner shelf; assemblage $\mathrm{D}$, sandy clay on the western inner middle shelf; assemblage $\mathrm{E}$, clay-rich fine sand to sandy clay on the eastern inner middle shelf; and assemblage $F$, sandy clay on the outer middle shelf (Fig. 1). Of the thirtythree bulk samples, 24 were surveyed for drillholes: 5 each from assemblages A and B, 6 from assemblage C, 4 from assemblage $\mathrm{D}$, and 2 each from assemblages $\mathrm{E}$ and $\mathrm{F}$.

Yazoo Formation. - The Yazoo Formation represents the deep-water facies of the Moodys Branch-Yazoo transgressive sequence. Cynthia Pit sediments were deposited in an "outer neritic" environment (Smith and Zumwalt, 1987), and were included to broaden the bathymetric range of our upper Eocene interval. Fossil recovery is generally poor in the Yazoo as the shells tend to be chalky and do not survive sieving. However, a quarry of the Jackson Ready-Mix Concrete Company in the Yazoo Formation at Cynthia, Mississippi, has exceptionally well-preserved fossils that are easily sieved. Twelve bulk samples were processed from Cynthia Pit.

\section{METHODS}

Sample Processing.-All of the collections come from bulk samples, which were wet sieved through a 1-mm screen. All shells were picked and identified, using the taxonomy of Palmer and Brann $(1965,1966)$, with modifications and additions from Bretsky (1976) and Dockery (1977). This process of collection and identification preserved relative abundances of species in the timeaveraged fossil assemblages. Because it was not possible to determine definitively whether incomplete specimens were drilled, we used only complete or nearly complete specimens in our analysis. Tables 1 and 2 list the number of complete specimens surveyed for drillholes from each sample; the study included 7749 specimens from the Cook Mountain interval and 17,364 from the Moodys Branch. Because of low numbers of specimens in the Cynthia Pit sam- 


\begin{tabular}{ccccccccccc}
0 & 10 & 20 & 30 & 40 & 50 & 60 & 70 & 80 & 90 & 100 \\
\hline & 1 & 1 & 1 & 1 & 1 & 1 & 1 & 1 & 1
\end{tabular}

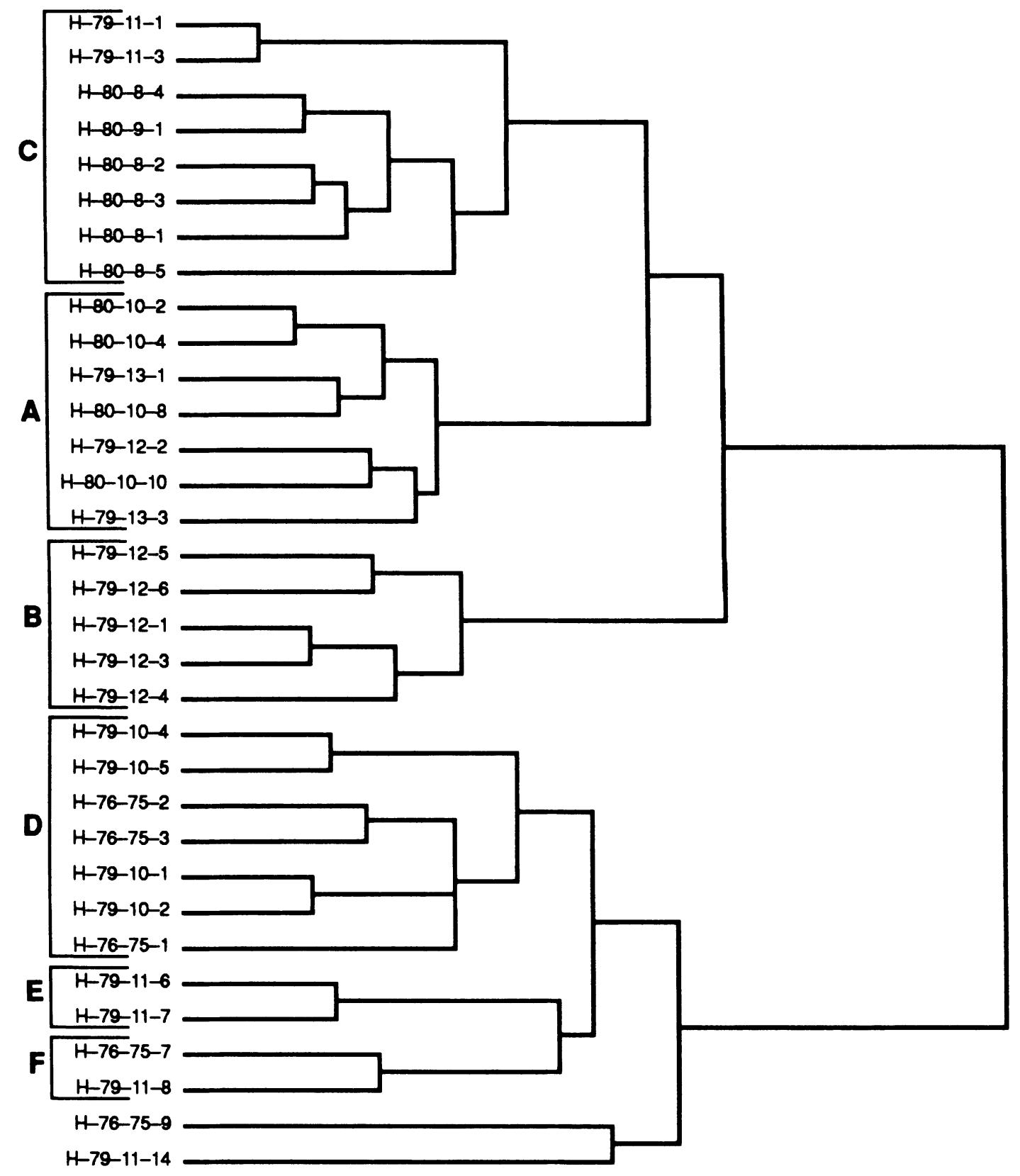

FIGURE 1-Cluster diagram for Q mode analysis of 33 samples from the Moodys Branch Formation. Letters A-F correspond to assemblages discussed in text.

ples, the 12 Yazoo samples were combined into one composite collection, which yielded 2441 specimens.

Roy et al. (manuscript) reported that modern Mulinia shells that have been drilled are significantly more likely to break under compressive forces than are undrilled shells. Thus drilled bivalve shells could be underrepresented in these samples because of selective breakage. Roy et al. listed several criteria to determine whether such a bias potentially exists in fossil assemblages. To evaluate the possi- bility of bias in this study, we examined thousands of specimens from two Cook Mountain samples, looking for degree of breakage and breaks through drillholes that would signify weakening of the shell by the hole. Although we found high numbers of 
TABLE 2-Sample size (measured as number of individuals, \# IND), diversity (measured by $R^{\prime}=S-1 / \log N$ ), percent naticids (\% NAT), mean grain size (GSIZE) and percent preferred species (\% PREF) for the Moodys Branch and Yazoo formations. Letter after sample number refers to assemblage; CP, Cynthia Pit.

\begin{tabular}{lrrrrr}
\hline \hline Sample & \# IND & $\mathrm{R}^{\prime}$ & $\%$ NAT & GSIZE & $\%$ PREF \\
\hline H79-13-1 A & 180 & 13 & 0 & 0.19 & 11.1 \\
H80-10-2 A & 157 & 10 & 1.9 & 0.28 & 35.4 \\
H80-10-4 A & 114 & 13 & 0.9 & 0.18 & 24.6 \\
H80-10-8 A & 105 & 11 & 2.9 & 0.50 & 16.7 \\
H80-10-10 A & 357 & 15 & 1.4 & 0.21 & 14.0 \\
H79-12-1 B & 143 & 11 & 0 & 0.37 & 22.7 \\
H79-12-3 B & 234 & 11 & 0 & 0.36 & 10.3 \\
H79-12-4 B & 289 & 8 & 0.4 & 1.00 & 6.2 \\
H79-12-5 B & 166 & 9 & 0 & 0.70 & 8.1 \\
H79-12-6 B & 232 & 9 & 0 & 0.44 & 3.7 \\
H79-11-1 C & 612 & 13 & 1.5 & 0.37 & 23.0 \\
H79-11-3 C & 1296 & 14 & 0.8 & 0.29 & 18.8 \\
H80-8-2 C & 740 & 12 & 0.3 & 0.26 & 13.1 \\
H80-8-3 C & 989 & 11 & 0.1 & 0.21 & 5.5 \\
H80-8-4 C & 718 & 13 & 0.4 & 0.40 & 10.6 \\
H80-8-5 C & 329 & 12 & 2.4 & 0.51 & 21.9 \\
H76-75-1 D & 398 & 10 & 0.5 & 0.11 & 18.2 \\
H76-75-2 D & 380 & 13 & 2.1 & 0.42 & 40.1 \\
H79-10-1 D & 235 & 11 & 2.6 & 0.40 & 30.4 \\
H79-10-4 D & 418 & 8 & 0.5 & 0.20 & 14.4 \\
H79-11-6 E & 389 & 12 & 0.8 & 0.30 & 18.8 \\
H79-11-7 E & 679 & 9 & 0 & 0.34 & 5.5 \\
H79-11-8 F & 82 & 9 & 0 & 0.26 & 21.5 \\
H76-75-4 F & 49 & 7 & 0 & 0.05 & 20.6 \\
CP & 1977 & 15 & 7.6 & 0.04 & 12.9 \\
\hline
\end{tabular}

fragmented shells, we also found substantial numbers of broken shells with complete drillholes (i.e., the breakage did not occur through a hole), arguing against such bias. The formations we have studied contain some of the best preserved fossil molluscan deposits in the world, with all shell mineralogies preserved and no evidence of tectonism or diagenetic alteration. Because of the excellent preservation of these deposits, taphonomic bias should be minimized here.

Data Tabulation.-Holes drilled by naticids generally are bevelled and parabolic in cross section, in contrast to straight-sided, unbevelled holes drilled by muricids. We examined specimens for naticid drillholes and recorded whether each drillhole completely penetrated the shell or was incomplete. Because of the magnitude of the study (27,554 specimens), it was not practical to identify comthe percentage of individuals (the toData Analysis. - For each sample,
drilling frequency was determined as

percentage by weight in each size fraction multiplied by the median grain size of that fraction. Data Analysis. - For each sample,
drilling frequency was determined as tal number of gastropod specimens plus one-half the number of pelecypod valves) with one or more complete drillholes. Similarly, the frequency of incomplete drillholes was calculated for each sample. Using techniques of correlation and linear regression, we then compared the frequencies of complete and incomplete drilling with latitude, depth, and mean grain size. We also related drilling to a variety of biological factors, including species diversity of the assemblage, percentage of naticids, and percentage of selected prey species.

\section{RESULTS}

The drilling frequencies of the Moodys Branch Formation were significantly different from those of both the Yazoo Formation (chi square = 49.58, $P \ll 0.001$ ) and the Cook Mountain interval (Mann-Whitney U-test, $P<0.001)$. Neither the Cook Mountain interval nor the Moodys Branch Formation showed a correlation between total drilling frequency and sample size as measured by the total number of individuals (Table 3). The frequency of complete drillholes for 15 samples of the Cook Mountain interval ranged from 6.8$38.7 \%$ with a mean of $22 \%$ (Table 4 ). Shells with incomplete drillholes represented $0-2.6 \%$ of the fauna (mean $=1.34 \%$ ). Overall drilling frequency (complete and incomplete drillholes) represented $23.2 \%$ of the fauna for the Cook Mountain interval. The frequency of complete drilling for the 24 Moodys Branch samples ranged from $3.0-21.9 \%$, with a mean of $8.3 \%$ (Table 5). Incomplete drillholes were present in $0-11.0 \%$ of the fauna $($ mean $=1.7 \%)$. Overall drilling frequency represented $9.9 \%$ of the fauna of the Moodys Branch Formation. The Yazoo composite sample had a drilling frequency of $21.2 \%$ and $0.8 \%$ for complete and incomplete drillholes respectively, yielding an overall drilling frequency of $22.0 \%$.

We examined the relationship of drilling to latitude by comparing Gulf Coast samples of the Cook Mountain interval with those from Virginia (Table 4). Frequencies of complete and incomplete drillholes were com- 
pared for the fauna as a whole, as well as for individual components such as bivalves, gastropods, all turritellid gastropods, and Turritella nasuta, the only species of Turritella present in both Virginia and the Gulf Coast samples. The drilling frequencies of the total fauna for Virginia (mean $=$ $30.3 \%, \mathrm{n}=4$ samples) were significantly higher than those for the Gulf Coast samples (mean $=18.0 \%, \mathrm{n}=$ 11 samples) as determined by the Mann-Whitney U-test $(P<0.01)$. Using the same test, no individual component of the Cook Mountain fauna differed significantly in drilling frequency between the Virginia and Gulf Coast samples.

Predation intensity has been shown to affect diversity in some living communities (Paine, 1966, 1981). For each sample, we calculated species diversity as $R^{\prime}=S-1 / \log N$ (where $S=$ number of species and $\mathrm{N}=$ number of individuals, Tables 1 and 2). The Moodys Branch showed a significant correlation of drilling frequency with $R^{\prime}(r=0.50, P<0.01)$. Within the Cook Mountain interval, there was no significant correlation between total drilling frequency and species diversity (Table 3 ).

Drilling frequency may also be related to the abundance of naticids. The percent of naticids in the Moodys Branch and Yazoo Formations was significantly correlated with the frequency of complete drillholes ( $\mathrm{r}=$ $0.77, \mathrm{P}<0.001$, Table 3). However, drilling frequency was not significantly correlated with the percent of naticids in the Cook Mountain fauna.

To relate drilling and substrate type, we performed a least-squares regression of grain size against the frequency of complete and incomplete drilling for each sample from the Cook Mountain interval and Moodys Branch Formation (Tables 1 and 2). Drilling intensity and grain size were not significantly correlated for either stratigraphic unit (Table 3).

Samples for the Moodys Branch Formation were combined into assemblages, which were compared along a depth gradient (Tables 6-8). The percentage of individuals with complete drillholes did not change

TABLE 3-Correlation coefficients ( $r$ values) for linear regressions of variables against percentage of individuals with complete drills (bivalves and gastropods combined). Asterisk indicates significance: ${ }^{*}=\mathrm{P}<0.05$, $^{\star \star}=$ $\mathrm{P}<0.01,^{\star * *}=\mathrm{P}<0.001$.

\begin{tabular}{lcc}
\hline \hline & Cook Mountain & Moodys Branch \\
\hline Sample size & 0.11 & 0.28 \\
Mean grain size & 0.40 & 0.18 \\
$\%$ Naticids & 0.31 & $0.77^{* * *}$ \\
$\%$ Bivalves & 0.26 & $-0.69^{* *}$ \\
$\%$ Preferred species & $0.58^{*}$ & $0.77^{* * *}$ \\
$\mathrm{R}^{\prime}=(\mathrm{S}-1 / \log \mathrm{N})$ & 0.40 & $0.50^{* *}$ \\
\hline
\end{tabular}

systematically with depth when the total fauna, bivalves, or gastropods were considered for Moodys Branch Assemblages A-F (Spearman's rank correlation coefficient, $r_{s}$, was nonsignificant in all cases; Table 6). Several widespread, frequently drilled species also showed no trend in predation with depth (Gonimyrtaea curta, G. subcurta, Corbula wailesiana, Turritella alveata, and Hipponix pygmaea; Table 7). Gonimyrtaea curta and T. alveata exhibited an increase between Moodys Branch assemblages A-E, but chi-square values were nonsignificant in either case. There was no significant rank correlation of percent incomplete drillholes with depth for the bivalves, gastropods, or for the total fauna (Table 8). However, the drilling frequency of the Yazoo assemblage (Cynthia Pit), which represented a deeper water environment than the Moodys Branch Formation, was significantly greater than the overall Moodys Branch drilling frequency (chi square $=49.58$ ) and greater than the drilling frequency of any single Moodys Branch assemblage (chi-square values range from 4.51 to 62.34).

Some ecological theory suggests that predators may choose their prey based on the abundance of that prey species in the community (Valentine, 1973). Within both the Cook Mountain and Moodys Branch, however, we found no overall correlation between the abundance of each species and its drilling frequency. Some species were drilled at frequencies much higher than their proportional representation in the assemblage. In the
Moodys Branch Formation, preferred prey species were Gonimyrtaea curta and G. subcurta, Hipponix pygmaea, Caestocorbula wailesiana, and Turritella alveata. These five species accounted for $40 \%$ of the total number of drilled individuals in the Moodys Branch Formation but only $16 \%$ of the total number of individuals. In the Cook Mountain interval, preferred prey species were Turritella sp., Lucina pomilia, and Pachecoa decisa. These three species accounted for $44 \%$ of the drilled individuals in the Cook Mountain interval and $24 \%$ of the total number of individuals. There was a significant correlation (Table 3) between the relative abundance of preferred prey in a sample and total drilling frequency of the sample in both the Moodys Branch Formation ( $r=0.80$, $P<0.001$; Fig. 2) and the Cook Mountain interval $(\mathrm{r}=0.585, \mathrm{P}<$ 0.05; Fig. 3).

\section{DISCUSSION}

The variability of drilling frequency in Eocene fossil assemblages (especially the Cook Mountain interval, in which drilling ranged from 6.8 to $38.7 \%$ ) was similar to that seen in modern environments (5-38\%; Vermeij, 1987). The mean $(8.3 \%)$ and range $(4-21.9 \%)$ of drilling frequencies in the Moodys Branch Formation were significantly less, though the values overlapped those for the Cook Mountain interval (this drop in drilling frequency between the Cook Mountain and Moodys Branch was associated with molluscan extinc- 
TABLE 4-Numbers of specimens without drills (ND), with complete beveled drills (CD), with incomplete drills (IC) and with unbeveled drills (UN) for the Cook Mountain interval. \% CD and \% IC in far right columns indicate overall percentages for numbers of individuals. Letter after sample number indicates location of outcrop: Virginia (V), Alabama (A), Louisiana (L), and Texas (T).

\begin{tabular}{lrrrrrrrrrr}
\hline \hline \multicolumn{1}{c}{ Sample } & ND & CD & IC & UN & ND & CD & IC & UN & $\%$ CD & $\%$ IC \\
\hline H76-64-2 V & 250 & 7 & 4 & 4 & 25 & 5 & 0 & 0 & 38.7 & 2.6 \\
H76-64-3 V & 305 & 84 & 4 & 2 & 57 & 7 & 0 & 0 & 34.8 & 1.8 \\
H76-64-5 V & 453 & 83 & 3 & 0 & 38 & 1 & 0 & 0 & 27.2 & 1.1 \\
H76-64-8 V & 413 & 48 & 3 & 0 & 4 & 0 & 1 & 0 & 20.3 & 1.9 \\
H76-31-3 A & 963 & 257 & 4 & 3 & 496 & 115 & 7 & 3 & 30.1 & 1.0 \\
H76-49-1 A & 337 & 16 & 1 & 0 & 74 & 8 & 1 & 0 & 9.2 & 0.8 \\
H76-52 A & 271 & 39 & 4 & 1 & 37 & 15 & 0 & 0 & 25.7 & 2.1 \\
H76-34-13A & 429 & 42 & 7 & 1 & 47 & 3 & 0 & 4 & 14.8 & 2.6 \\
H76-27-1 A & 464 & 56 & 5 & 4 & 51 & 5 & 0 & 0 & 19.0 & 1.7 \\
H76-76-1 L & 321 & 14 & 4 & 0 & 77 & 3 & 1 & 0 & 6.8 & 2.1 \\
H76-73-7 T & 3 & 1 & 0 & 0 & 205 & 68 & 4 & 3 & 24.5 & 1.4 \\
H76-73-8 T & 5 & 1 & 0 & 0 & 555 & 77 & 1 & 0 & 12.3 & 0.2 \\
H76-69-1 T & 8 & 2 & 1 & 0 & 191 & 27 & 0 & 0 & 13.0 & 0.5 \\
H76-69-2 T & 2 & 0 & 0 & 0 & 245 & 52 & 0 & 0 & 17.4 & 0 \\
H76-69-4 T & 1 & 1 & 1 & 0 & 182 & 61 & 0 & 0 & 25.4 & 0.4 \\
\hline
\end{tabular}

TABLE 5-Numbers of specimens without drills (ND), with complete beveled drills (CD), with incomplete drills (IC) and with unbeveled drills (UN) for the Moodys Branch and Yazoo formations. \% CD and \% IC in far right columns indicate overall percentages for numbers of individuals. Letter after sample number indicates assemblage designation and relative position on an onshore-offshore gradient.

\begin{tabular}{lrrrrrrrrrr}
\hline \hline \multicolumn{1}{c}{ Sample } & ND & CD & IC & UN & ND & CD & IC & UN & \% CD & $\%$ IC \\
\hline H79-13-1 A & 289 & 8 & 1 & 1 & 28 & 1 & 1 & 0 & 5.0 & 1.1 \\
H80-10-2 A & 241 & 18 & 0 & 3 & 24 & 2 & 0 & 0 & 13.3 & 0 \\
H80-10-4 A & 183 & 13 & 2 & 0 & 14 & 1 & 0 & 0 & 12.3 & 1.8 \\
H80-10-8 A & 143 & 14 & 4 & 3 & 23 & 0 & 0 & 0 & 13.2 & 3.8 \\
H80-10-10 A & 540 & 35 & 3 & 0 & 64 & 4 & 0 & 0 & 11.5 & 0.8 \\
H79-12-1 B & 195 & 9 & 0 & 0 & 33 & 6 & 1 & 1 & 10.5 & 0.7 \\
H79-12-3 B & 393 & 19 & 0 & 1 & 24 & 3 & 0 & 0 & 9.3 & 0 \\
H79-12-4 B & 516 & 11 & 2 & 1 & 24 & 0 & 0 & 0 & 4.0 & 0.7 \\
H79-12-5 B & 300 & 5 & 1 & 0 & 13 & 0 & 0 & 0 & 3.0 & 0.6 \\
H79-12-6 B & 427 & 9 & 2 & 1 & 5 & 1 & 6 & 0 & 4.2 & 3.5 \\
H79-11-1 C & 893 & 46 & 1 & 0 & 126 & 16 & 0 & 0 & 10.0 & 0.2 \\
H79-11-3 C & 2166 & 99 & 2 & 16 & 130 & 24 & 0 & 0 & 9.2 & 0.2 \\
H80-8-2 C & 1310 & 35 & 1 & 5 & 60 & 3 & 1 & 0 & 5.2 & 0.3 \\
H80-8-3 C & 1809 & 47 & 43 & 7 & 32 & 4 & 0 & 0 & 5.1 & 4.3 \\
H80-8-4 C & 1209 & 43 & 4 & 1 & 81 & 8 & 0 & 0 & 7.1 & 0.6 \\
H80-8-5 C & 496 & 37 & 4 & 0 & 55 & 5 & 0 & 0 & 13.2 & 1.2 \\
H76-75-1 D & 676 & 17 & 1 & 7 & 43 & 4 & 0 & 0 & 5.1 & 0.3 \\
H76-75-2 D & 526 & 69 & 16 & 0 & 59 & 12 & 3 & 0 & 21.9 & 5.0 \\
H79-10-1 D & 335 & 24 & 5 & 0 & 44 & 9 & 0 & 0 & 14.0 & 2.1 \\
H79-10-4(D) & 762 & 29 & 2 & 4 & 14 & 4 & 1 & 0 & 7.6 & 0.7 \\
H79-11-6(E) & 518 & 30 & 8 & 1 & 90 & 17 & 3 & 0 & 11.6 & 2.8 \\
H79-11-7(E) & 1159 & 64 & 23 & 5 & 48 & 3 & 2 & 0 & 10.1 & 3.7 \\
H79-11-8(F) & 115 & 7 & 2 & 1 & 12 & 0 & 7 & 0 & 9.9 & 11.0 \\
H76-75-4(F) & 84 & 3 & 3 & 1 & 2 & 0 & 1 & 0 & 6.5 & 8.2 \\
Cynthia Pit & 837 & 86 & 4 & 1 & 1157 & 333 & 12 & 11 & 21.2 & 0.8 \\
\hline
\end{tabular}


tions and climate change; Kelley and Hansen, 1993). However, the range of drilling frequencies in both horizons indicates that samples from many different paleoenvironments are required to adequately characterize the drilling frequency for a particular time. Studies of drilling frequency based on one or two samples from a single locality must be viewed with great caution if these samples are used to represent the predation intensity "characteristic" of a particular time.

We found a correlation of predation intensity with latitude. Although selected components of the fauna showed no significant differences with latitude, drilling frequencies for the fauna as a whole were significantly greater in Virginia samples than those for the Gulf Coast. This result is in accord with observations of an equatorward decrease in drilling on modern bivalves (Vermeij et al., 1989) and Paleocene turritellids (Allmon et al., 1990). An equatorward decrease in drilling contradicts a perhaps more widely held view that "drilling gastropod predators are strikingly more diverse, and they have a greater impact ecologically in the tropics than in the temperate zones" (Vermeij, 1987, p. 172; Taylor and Taylor, 1977; Vermeij and Dudley, 1982).

The Moodys Branch and Yazoo Formations were used to assess environmental and biological constraints on drilling, because of their tight paleoenvironmental control. In addition, these samples represent a narrow latitudinal range, so that complications due to variation in paleoclimate are avoided.

Species diversity and drilling frequency were correlated within the Moodys Branch Formation. This relationship is consistent with the hypothesis that predators may increase diversity within communities by preventing monopolization of resources by dominant species (Paine, 1966).

Depth did not correlate with drillhole frequency within the Moodys Branch Formation for the fauna as a whole or for selected widespread species (Tables 6 and 7). There was also no significant correlation between
TABLE 6-Percentage of individuals with complete drills in the Moodys Branch Formation. Assemblages A-F represent a general onshore to offshore gradient ( $F$ is furthest offshore). Numbers of specimens are in parentheses. There is no significant trend with depth as determined by Spearman's Rank Correlation Coefficient (differences of $0.1 \%$ were treated as ties).

\begin{tabular}{lcccccc}
\hline \hline & \multicolumn{7}{c}{ Assemblage } & \multirow{2}{*}{ CP } \\
\cline { 2 - 6 } & $\mathrm{A}$ & $\mathrm{B}$ & $\mathrm{C}$ & $\mathrm{D}+\mathrm{E}$ & $\mathrm{F}$ & \\
\hline Bivalves & $11.7 \%$ & $5.6 \%$ & $7.4 \%$ & $10.9 \%$ & $9.3 \%$ & $18.5 \%$ \\
& $(1501)$ & $(1892)$ & $(8273)$ & $(4281)$ & $(216)$ & $(928)$ \\
Gastropods & $9.9 \%$ & $3.9 \%$ & $11.2 \%$ & $13.8 \%$ & 0 & $22 \%$ \\
& $(162)$ & $(259)$ & $(545)$ & $(356)$ & $(22)$ & $(1513)$ \\
Total & $9.0 \%$ & $5.7 \%$ & $7.8 \%$ & $10.9 \%$ & $7.7 \%$ & $21.1 \%$ \\
\hline
\end{tabular}

depth and incomplete drillholes within the Moodys Branch. The lack of a clear trend between drilling frequency and depth on the Paleogene inner to middle shelf is in accord with our limited modern data base in which the trend is vague at best (Sander and Lalli, 1982). We did, however, find significantly greater drilling within the outer shelf Yazoo Formation.

The intense predation pressure in the Yazoo can be explained by the high proportion of naticids in the $\mathrm{Ya}$ zoo. The Yazoo assemblage contains a much larger percentage of naticids than does the Moodys Branch (7.58\% vs. $0-2.85 \%$ ) and many more carnivorous gastropods overall, especially of the family Turridae. A molluscan fauna rich in carnivores, including high densities of naticids, is typical of marine communities living at depths greater than $200 \mathrm{~m}$, where primary productivity is reduced and suspension-feeding less important (Hickman, 1984). This relationship suggests that depth is related to drilling frequencies only insofar as depth influences the percentage of naticids in an assemblage. Indeed, there is a significant correlation between the abundance of naticids and drilling frequencies in the Moodys Branch Formation. In addition, the significantly higher overall drilling frequency in the Cook Mountain interval, as compared with the Moodys Branch, is mirrored by a greater abundance of naticids $(9 \%)$ in the
TABLE 7-Percentage of individuals of preferred species with complete drills in the Moodys Branch and Yazoo formations. Assemblages A and B were combined to increase sample sizes (sample size in parentheses). $X$ not present.

\begin{tabular}{|c|c|c|c|c|c|}
\hline & \multicolumn{4}{|c|}{ Assemblage } & \multirow[b]{2}{*}{$\mathrm{CP}$} \\
\hline & $A+B$ & $\mathrm{C}$ & $\mathrm{D}+\mathrm{E}$ & $F$ & \\
\hline G. curta & $\begin{array}{l}15 \% \\
(156)\end{array}$ & $\begin{array}{l}18 \% \\
(311)\end{array}$ & $\begin{array}{c}24 \% \\
(132)\end{array}$ & $\begin{array}{l}0 \\
(3)\end{array}$ & $\begin{array}{l}18 \% \\
(11)\end{array}$ \\
\hline G. subcurta & $\begin{array}{l}39 \% \\
(169)\end{array}$ & $\begin{array}{c}34.1 \% \\
(387)\end{array}$ & $\begin{array}{r}43.8 \% \\
(64)\end{array}$ & $\begin{array}{r}33 \% \\
(6)\end{array}$ & $\mathrm{X}$ \\
\hline C. wailesiana & $\begin{array}{c}17.3 \% \\
(127)\end{array}$ & $\begin{array}{c}9.7 \% \\
(103)\end{array}$ & $\begin{array}{l}24.4 \\
(443)\end{array}$ & $\begin{array}{c}0 \\
(18)\end{array}$ & $\begin{array}{c}24.6 \% \\
(505)\end{array}$ \\
\hline T. alveata & $\begin{array}{r}13.9 \% \\
(72)\end{array}$ & $\begin{array}{c}18.4 \% \\
(87)\end{array}$ & $\begin{array}{r}23.8 \% \\
(63)\end{array}$ & $\begin{array}{l}0 \\
(0)\end{array}$ & $\mathrm{X}$ \\
\hline H. pygmaea & $\begin{array}{c}5.9 \% \\
(17)\end{array}$ & $\begin{array}{c}21.8 \% \\
(124)\end{array}$ & $\begin{array}{c}16 \% \\
(94)\end{array}$ & $\begin{array}{c}0 \\
(22)\end{array}$ & $\mathrm{X}$ \\
\hline
\end{tabular}


TABLE 8-Percentage of individuals with incomplete drills along an onshore-offshore gradient in the Moodys Branch Formation. See Table 2 for sample sizes.

\begin{tabular}{lcccccc}
\hline \hline & \multicolumn{5}{c}{ Assemblage } & \\
\cline { 2 - 6 } & $\mathrm{A}$ & $\mathrm{B}$ & $\mathrm{C}$ & $\mathrm{D}+\mathrm{E}$ & $\mathrm{F}$ & CP \\
\hline Bivalves & $1.3 \%$ & $0.5 \%$ & $1.3 \%$ & $2.6 \%$ & $4.6 \%$ & $0.9 \%$ \\
Gastropods & $0.6 \%$ & $2.7 \%$ & 0 & $2.5 \%$ & $36.4 \%$ & $0.8 \%$ \\
Total & $1.2 \%$ & $1.0 \%$ & $1.2 \%$ & $2.6 \%$ & $10.0 \%$ & $0.8 \%$ \\
\hline
\end{tabular}

Cook Mountain. On the other hand, there is no correlation between the abundance of naticids and drilling frequency within the Cook Mountain interval.

Assuming that drilling frequency is a function of naticid abundance, what factors control the occurrence of naticids? Possible factors that we considered were substrate type and availability of prey. Because naticids are infaunal gastropods that plow through the substrate beneath the sediment surface, we expected that substrate type might influence their distribution. However, we found no relationship between grain size and drilling frequency within either the
Moodys Branch Formation or Cook Mountain interval.

The significant correlation bespecies" and drilling frequency within assemblages of the Cook Mountain and Moodys Branch (the only correlation common to both stratigraphic levels; Figs. 2 and 3) suggests that naticid drilling frequencies were partially controlled by the availability of suitable prey species. The inability of naticids to compensate for the lack of preferred prey, by increasing predation on other species, may be due to high cost: benefit values for the alternative prey in the assemblages where predation intensity is low. tween percentage of "preferred prey

\section{Moodys Branch}

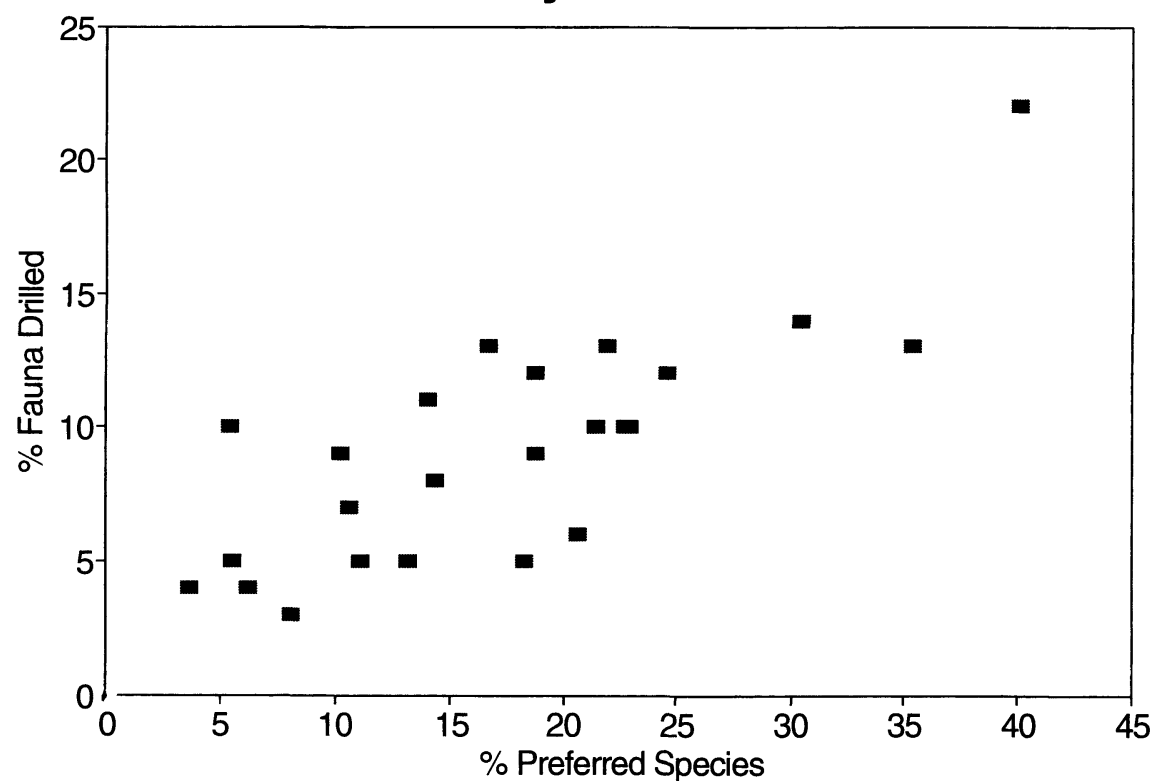

FIGURE 2-Percentage of fauna with complete drills plotted against percentage of fauna comprised of preferred species (Gonimyrtaea curta, G. subcurta, Hipponix pygmaea, Caestocorbula wailesiana, and Turritella alveata) for the Moodys Branch Formation.
(Cost: benefit values are represented by the ratio of drilling time : energy gained, as reflected by shell thickness : internal volume; Kitchell et al., 1981; Kitchell, 1982; Kelley, 1988, 1991.) An abundance of high-cost prey would simply make it too hard for many naticids to make a living. The correlation of drilling frequency and percentage of preferred prey may also reflect the behavioral stereotypy of naticids (Boggs et al., 1984; Kitchell, 1986). Naticid prey selectivity may develop over evolutionary time based on cost-benefit factors. In the short term (within an individual lifetime), however, naticids may have difficulty adjusting to the absence of these preferred species by targeting others. Thus, when preferred species are absent, overall drilling frequencies are lower. (Ongoing work explores the cost: benefit relationships between preferred species and less frequently drilled prey.)

There is a remarkable consistency in the families that were preferred as prey by naticids for the entire Paleogene, a period of over 30 million years (Kelley and Hansen, 1993). The preferred species in the Moodys Branch Formation were from the families Lucinidae, Turritellidae, Corbulidae, and Hipponicidae. In the Cook Mountain interval, preferred prey included species of the Lucinidae, Noetiidae, and Turritellidae. (All of these preferred prey were slow-moving infaunal burrowers, with the exception of the hipponicid, which was a slowmoving, epifaunal, possibly commensal species.) In other Paleogene horizons, there were typically only one or two preferred species in each level and they were always in the families Lucinidae, Corbulidae, or Turritellidae (Kelley and Hansen, 1993). Examples are: Phacoides sp. (Lucinidae) and Haustator gnoma (Turritellidae) in the Brightseat Formation of Maryland (Paleocene), Mesalia (Turritellidae) in the Bells Landing Member of Alabama (Paleocene), Turritella aldrichi from the Matthews Landing Member of Alabama (Paleocene), Corbula subengonata and Vokesula aldrichi (both Corbulidae) in the Bashi Formation of Alabama (lower Eocene), Corbula ru- 
faripa from the Red Bluff Formation of Mississippi (Oligocene), and Corbula laqueata from the Mint Springs Formation of Mississippi (Oligocene).

Such a long-term assault on these particular families by naticids may reflect an inability of the prey to escalate into a high cost : benefit range. However, the Turritellidae and Corbulidae showed significant increases in percentages of incomplete and multiple boreholes from the Cretaceous through Oligocene, suggesting some increase in prey defensive ability (Kelley and Hansen, 1993). Longterm prey preference may also be further evidence for behavioral stereotypy by naticids on evolutionary time scales. This long term inflexibility with regard to prey species may explain the decline of naticid drilling frequencies around the CretaceousTertiary and Eocene-Oligocene extinction events (Kelley and Hansen, 1993). Naticids may have been too stereotyped to respond rapidly to large fluctuations in the populations of preferred prey species during extinction episodes. Only on an evolutionary time scale could naticids develop new behaviors to cope with the restructured ecosystem. This restructuring may also have presented new opportunities for escalation, as in the Paleocene recovery, during which naticid drilling frequencies more than doubled over those in the Cretaceous (Kelley and Hansen, 1993).

\section{CONCLUSIONS}

1) Frequencies of drilling by naticid gastropods varied among geographic samples within the middle Eocene Cook Mountain interval $(6.8-38.7 \%)$ and upper Eocene Moodys Branch Formation $(4.0-21.9 \%)$ of the Gulf and Atlantic Coastal Plain. Therefore, in order to characterize the drilling frequency that existed at a particular time, samples from a variety of paleoenvironments should be examined.

2) Naticid gastropod drilling frequencies were significantly great-

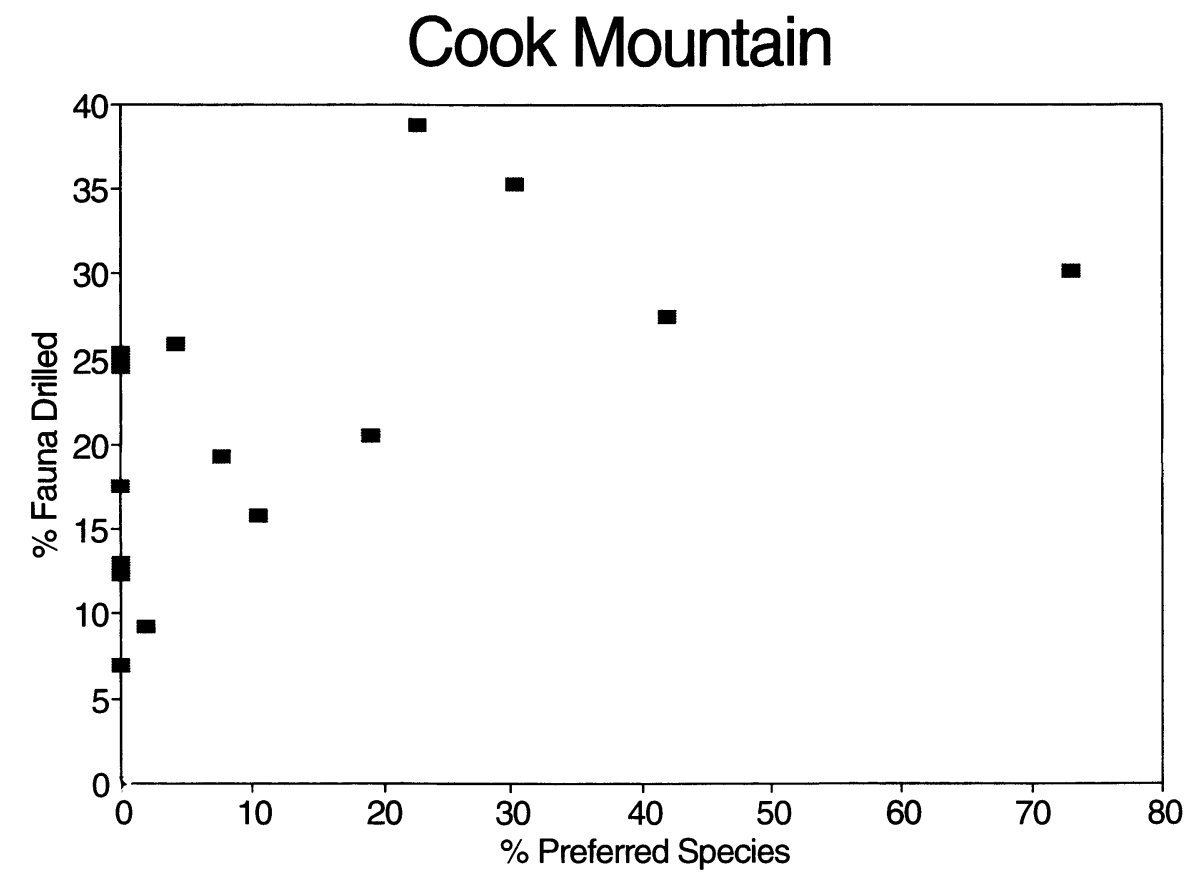

FIGURE 3-Percentage of fauna with complete drills plotted against percentage of fauna comprised of preferred species (Turritella sp., Lucina pomilia, and Pachecoa decisa) for the Cook Mountain interval.

er for Virginia samples of the Cook Mountain interval than for those from the Gulf Coast. Results are consistent with a previously reported equatorward decrease in drilling frequencies of molluscs.

3) We found no consistent trend in drilling frequencies with depth or grain size within the Moodys Branch Formation, although the deeper-water Yazoo Formation exhibited a significantly greater frequency of drilling than did the Moodys Branch.

4) There was a significant correlation of drilling frequency with species diversity of Moodys Branch assemblages. This result is consistent with the hypothesis that predation promotes high diversity.

5) Drilling frequency was significantly correlated with naticid abundance within the Moodys Branch Formation. High drilling frequencies in the entire Cook Mountain interval and the Yazoo Formation were also accompanied by high proportions of naticids.

6) Some species suffered dispropor- tionately high drilling frequencies. The abundance of these preferred prey species was significantly correlated with drilling frequency, such that when these preferred prey were uncommon in a sample, overall drilling frequency was low. This relationship may reflect a behavioral inflexibility in naticid predation patterns.

7) Slow-moving infaunal species, particularly of the families Turritellidae, Corbulidae, and Lucinidae, were commonly preferred as prey in these Eocene assemblages and in other Paleogene formations. Such long-term victimization over tens of millions of years may reflect the prey's inability to escalate out of danger. Alternatively, predation may be a less effective agent of selection than other factors acting on these preferred prey taxa.

\section{ACKNOWLEDGMENTS}

We thank David Dockery for directing us to the Cynthia Pit locality, and David Haasl for assistance in the 
field. Ray Ferris, David Haasl, Ben Farrell, and Elizabeth Akins assisted in data tabulation. This study was supported by National Science Foundation grant EAR 8915725 and a Summer Research Award from Western Washington University.

\section{REFERENCES}

Allmon, W.D., NiEH, J.C., and NorRis, R.D., 1990, Drilling and peeling of turritelline gastropods since the Late Cretaceous: Palaeontology, v. 33, p. 595-611.

$\rightarrow$ BogGs, C.H., RICE, J.A., KITCHELl, J.A., and Post, W.M., 1984, Predation at a snail's pace: What's time to a gastropod?: Oecologia, v. 62 , p. 13-17.

BRETSKY, S.S., 1976, Evolution and classification of the Lucinidae (Mollusca; Bivalvia): Palaeontographica Americana, v. $8,337 \mathrm{p}$.

DAvis, R.A., JR., 1962, Paleoecology of the Hurricane Lentil, Cook Mountain Formation (Eocene), East Texas: The Texas Journal of Science, v. 14, p. 352-364.

Dockery, D.T., III, 1976, Depositional systems in the Upper Claiborne and Lower Jackson groups (Eocene) of Mississippi: Unpublished M.S. Thesis, University of Mississippi, Jackson, 109 p.

Dockery, D.T., III, 1977, Mollusca of the Moodys Branch Formation, Mississippi: Mississippi Geological Survey Bulletin, v. 120,212 p.

Dudley, E.C., and VermeiJ, G.J., 1978, Predation in time and space: Drilling in the gastropod Turritella: Paleobiology, v. 4, p. 436-441.

Elder, S.R., and Hansen, T.A., 1981, Macrofossil assemblages of the Moodys Branch Formation (Upper Eocene), Louisiana and Mississippi: Mississippi Geology, v. 2, p. 6-11.

GARDNER, J.A., 1957, Little Stave Creek, Alabama-paleoecological study: in LADD, H.S., ed., Treatise on marine ecology and paleoecology: Geological Society of America, Memoir 67, v. 2, p. 573-587.

HANSEN, T.A., 1980, Influence of larval dispersal and geographic distribution on species longevity in neogastropods: $\mathrm{Pa}-$ leobiology, v. 6, p. 193-207.

Hickman, C.S., 1984, Composition, structure, ecology, and evolution of six Cenozoic deep-water mollusk communities:
Journal of Paleontology, v. 58, p. 1215 1234.

$\rightarrow$ Kelley, P.H., 1988, Predation by Miocene gastropods of the Chesapeake Group: Stereotyped and predictable: PALAIOS, v. 3, p. 436-448.

Kelley, P.H., 1991, Cannibalism by Chesapeake Group naticid gastropods: A predictable result of stereotyped predation: Journal of Paleontology, v. 65, p. 75-79.

$\rightarrow$ Kelley, P.H., and HANSEN, T.A., 1993, Evolution of the naticid gastropod predatorprey system: An evaluation of the hypothesis of escalation. PALAIOS, v. 8, p. 358-375.

KiTCHELL, J.A., 1982, Coevolution in a predator-prey system: Third North American Paleontological Convention, Proceedings, v. 2, p. 301-305.

KITCHELL, J.A., 1986, The evolution of predator-prey behavior: Naticid gastropods and their molluscan prey: in NITECKI, M., and KITCHELL, J.A., eds., Evolution of Animal Behavior: Paleontological and Field Approaches: Oxford University Press, Oxford, p. 88-110.

KrTChell, J.A., BogGs, C.H., KITCHell, J.F., and RICE, J.A., 1981, Prey selection by naticid gastropods: Experimental test and application to the fossil record: Paleobiology, v. 7, p. 533-552.

Kitchell, J.A., Boggs, C.H., Rice, J.A., Kitchell, J.F., Hoffman, A., and MARTINELl, J., 1986, Anomalies in naticid predatory behavior: A critique and experimental observations: Malacologia, $\mathrm{v}$. 27, p. 291-298.

MarinCovich, L., JR., 1977, Cenozoic Naticidae (Mollusca: Gastropoda) of the northeastern Pacific. Bulletins of American Paleontology, v. 70, p. 169-494.

PaIne, R.T., 1966, Food web complexity and species diversity: American Naturalist, v. 100 , p. $65-75$.

Paine, R.T., 1981, The forgotten roles of disturbance and predation: Paleobiology, v. 7, p. 553-560.

Palmer, K.V.W., and BranN, D.C., 1965, 1966, Catalogue of the Paleocene and Eocene Mollusca of the Southern and Eastern United States: Bulletins of American Paleontology, v. 48, 1027 p.

$\rightarrow$ Roy, K., Miller, D.J., and LABARBera, M., 1994, Taphonomic bias in analysis of drilling predation: Effects of gastropod drill holes on bivalve shell strength: PALAIOS, v. 9, p. 413-421.

Sander, F., and Lalli, C.M., 1982, A com- parative study of the mollusk communities on the shelf-slope margin of Barbados, West Indies: Veliger, v. 24, p. 309 318.

SMITH, S.M., and Zumwalt, G.S., 1987, Gravity flow introduction of shallow water microfauna into deep water depositional environments: Mississippi Geology, v. 8 , p. 1-7.

STRICKLAND, G.L., 1984, Molluscan biozones of the Piney Point Formation (Middle Eocene, Claibornian Age) in the Pamunkey River valley, Virginia: in WARD, L.W., and KRAFFT, K., eds., Stratigraphy and Paleontology of the Outcropping Tertiary Beds in the Pamunkey River Region, Central Virginia Coastal Plain: Guidebook for the 1984 Field Trip, Atlantic Coastal Plain Geological Association, p. 155-182.

TAYLOR, J.D., and TAYLOR, C.W., 1977, Latitudinal distribution of predatory gastropods on the eastern Atlantic shelf: Journal of Biogeography, v. 4, p. 73-81.

VALentine, J.W., 1973, Evolutionary Paleoecology of the Marine Biosphere: Prentice-Hall, Inc., Englewood Cliffs, New Jersey, $511 \mathrm{p}$.

VERMEIJ, G.J., 1980, Drilling predation on bivalves in Guam: Some paleoecological implications: Malacologia, v. 19, p. 3329 3334.

VERMEIJ, G.J., 1987, Evolution and Escalation: An Ecological History of Life: Princeton University Press, Princeton, $527 \mathrm{p}$.

VeRMeiJ, G.J., and Dudley, E.C., 1982, Shell repair and drilling in some gastropods from the Ripley Formation (Upper Cretaceous) of the south-eastern U.S.A.: Cretaceous Research, v. 3, p. 397-403.

VermeiJ, G.J., Dudley, E.C., and ZIPSER, E., 1989, Successful and unsuccessful drilling predation in Recent pelecypods: Veliger, v. 32, p. 266-273.

W ARD, L.W., 1984, Stratigraphy of outcropping Tertiary beds along the Pamunkey River-Central Virginia coastal plain: in WARD, L. W., and KRAFFT, K., eds., Stratigraphy and Paleontology of the Outcropping Tertiary Beds in the Pamunkey River Region, Central Virginia Coastal Plain: Guidebook for the 1984 Field Trip, Atlantic Coastal Plain Geological Association, p. 11-78.

ACCEPTED MAY 31, 1994 